\title{
Pengelolaan Drainase Kota Sebagai Upaya Mitigasi Banjir Kota Makassar
}

\author{
Ibrahim Djamaluddin $^{1 *}$, Sumarni Hamid Aly ${ }^{1}$, Irwan Ridwan Rahim ${ }^{1}$, Achmad Zubair ${ }^{1}$, Roslinda \\ Ibrahim $^{1}$, Nurjannah Oktorina Abdullah ${ }^{1}$ \\ Departemen Teknik Lingkungan, Fakultas Teknik Universitas Hasanuddin ${ }^{1}$ \\ ibedije@gmail.com*
}

\begin{abstract}
Abstrak
Banjir Kota Makassar dipengaruhi oleh dua faktor utama, yaitu: faktor alam seperti curah hujan dan topografi, dan faktor manusia dengan segala aktivitasnya yang dapat mempengaruhi sistem drainase dan keadaan penutupan lahan di atasnya. Sebagian besar sistem drainase air di Kota Makassar hanya mengandalkan jaringan pembuangan dari saluran kecil ke saluran besar seperti kanal yang umumnya dialirkan secara gravitasi ke laut sehingga daerah-daerah yang telah mengalami perubahan fungsi tutup lahan yang dahulunya resapan air menjadi urban area sangat mudah terjadi genangan atau banjir sebab pengaliran air tidak dapat berjalan dengan baik mengakibatkan banjir sering terjadi, apalagi di daerah yang memiliki permukaan tanah yang rendah. Aquapond adalah salah satu sistem kolam retensi yang banyak digunakan di Jepang yang berfungsi sebagai penyimpanan air hujan sementara saat curah hujan tinggi dan mengalirkannya secara perlahan setelah curah hujan mereda sebagai salah satu solusi teknik pengelolaan drainase air perkotaan yang sering mengalami luapan aliran air atau banjir setempat. Kolam retensi teknologi Jepang seperti Aquapond ini diujicobakan di satu tempat yang sering mengalami banjir setiap tahunnya di Kota Makassar yaitu di Jalan Urip Sumohardjo depan kantor gubernur Sulawesi Selatan yang diharapkan dapat berguna pada pengelolaan sistem drainase air yang sering meluap dan mengakibatkan banjir yang mengganggu arus lalu lintas jalanan. Karena sistem kolam retensi yang tersambung dengan saluran drainase air, metode pengelolaan air ini belum banyak dipahami oleh masyarakat umum dan pemerintah setempat, sehingga kegiatan pembelajaran dan sosialisasi tentang perencanaan dan desain, konstruksi serta operasional dan pemeliharaan kolam retensi Aquapond dilaksanakan. Proses pelaksanaan kegiatan pengabdian ini telah melibatkan masyarakat, pemerintah setempat dan pihak Jepang baik dalam proses pembelajaran dalam perencanaan dan desain, peninjauan konstruksi Aquapond, dan tinjauan lapangan operasional dan pemeliharaan fasilitas. Kegiatan ini menghasilkan pembelajaran secara menyeluruh dan sekaligus sosialisasi tentang pemanfaatkan kolam retensi Aquapond untuk mitigasi banjir kepada pemerintah setempat dan masyakarat umum melalui kegiatan seminar dan diskusi sharing knowledge. Lebih dari itu, mengkaji bersama-sama dengan pihak Jepang dan pemerintah terkait tentang permasalahan-permasalahan pengelolaan drainase kota menggunakan fungsi kolam retensi Aquapond dan mendiskusikan teknis penanganannya.
\end{abstract}

Kata Kunci: Mitigasi Banjir; Sistem Retensi Air; Drainase Kota; Aquapond; Teknologi Jepang.

\begin{abstract}
Floods in Makassar City are influenced by two main factors, namely: natural factors such as rainfall and topography, and human factors with all their activities that can affect the drainage system and the state of land cover. Most of the water drainage system in Makassar City only relies on the drainage network from small channels to large channels such as canals which are generally flowed by gravity into the sea, so that areas that have undergone a change in land cover function that were previously water infiltration into urban areas are very easy to floods because water drains cannot run properly resulting in frequent flooding, especially in areas that have low ground levels. Aquapond is a retention pond system that is widely used in Japan which functions as a temporary storage of rainwater when rainfall is high and drains it slowly after the rainfall subsides as a solution to urban water drainage management techniques which often experience overflow of water or flooding. Japanese technology retention ponds such as Aquapond were piloted in one place that often experiences flooding every year in Makassar City, namely Jalan Urip Sumohardjo in front of the South Sulawesi governor's office which is expected to be useful in managing the water drainage system which often overflows and causes flooding that disrupts traffic of road. Because the retention pond system is connected to water drainage channels, this water management method is not widely understood by the general public and the local government, so learning and outreach activities regarding planning and design, construction as well as operation and maintenance of Aquapond retention ponds are carried out. The process of implementing this service activity has involved the community, local government and Japanese
\end{abstract}


experts both in the learning process in planning and design, reviewing Aquapond construction, and field reviews of facility operations and maintenance. This activity resulted in comprehensive learning and at the same time socialization about the use of Aquapond retention ponds for flood mitigation to the local government and the general public through seminars and knowledge sharing discussions. Moreover, the problems of urban drainage management using the Aquapond are discussed.

Keywords: Flood Mitigation; Water Retention System; City Drainage; Aquapond; Japanese Technology.

\section{Pendahuluan}

Banjir adalah salah satu masalah utama tidak hanya sering terjadi di Kota Makasasar tapi hampir di seluruh kota-kota besar di Indonesia. Peristiwa banjir khususnya di musim hujan setiap tahun berulang, namun permasalahan ini sampai saat ini belum terselesaikan dengan baik, bahkan cenderung makin meningkat, baik frekuensinya, luasannya, kedalamannya, maupun durasinya (Anonim, 2019). Salah satu penyebab terjadinya banjir adalah perubahan fungsi tutup lahan yang signifikan dan buruknya penataan sistem jaringan drainase. Besarnya volume air hujan tidak sebanding lagi dengan daya tampung sistem drainase yang telah direncanakan. Sebagai solusi atas hal tersebut, sering dilakukan kegiatan normalisasi dan rehabilitasi dengan menambah volume saluran drainase serta pembersihan saluran akibat sedimen dan sampah. Namun dalam pelaksanaannya, kegiatan normalisasi tersebut dinilai tidak efektif dan sulit dilakukan dikarenakan kondisi seperti permukaan tanah yang rendah dan datar.

Tingginya aktivitas masyarakat urban akibat pertambahan jumlah penduduk telah mempengaruhi minimnya lahan hijau dan wilayah serapan hujan yang digunakan untuk menyediakan prasarana dan sarana perkotaan termasuk drainase air. Oleh karena itu, dibutuhkan strategi baru dalam pengelolaan sistem drainase di Kota Makassar yang memiliki masalah seperti permukaan tanah yang relatif rendah, muka air laut yang tinggi, dan keterbatasan lahan hijau. Salah satu strategi pengelolaan drainase air dalam upaya mitigasi banjir perkotaan adalah pemanfaatan kolam retensi melalui pembangunan penampungan air hujan bawah tanah. Penampungan air bawah tanah yang terhubungkan dengan jaringan drainase kota merupakan salah satu solusi yang handal dan banyak berkembang sebagai sistem yang efektif dalam mitigasi banjir perkotaan seperti yang ada sekarang di Jepang. Sebagai contoh, dibangunnya fasilitas kolam retensi air hujan bawah tanah yang dinamakan Aquapond di Kota Fukuoka, Kyushu, Jepang. Fasilitas Aquapond tersebut banyak dibangun untuk mencegah meluapnya drainase dengan mengalirkan air masuk ke dalam kolam retensi yang telah dirancang penempatannya dan sistem pengelolaannya pada saat curah hujan tinggi (Ishida et al., 2003).

Bantuan dari pihak Jepang, pemerintah Kota Makassar saat ini telah membangun kolam retensi Aquapond sebagai ujicoba sistem pengelolaan drainase air dalam rangka mewujudkan sistem drainase yang berkelanjutan dan berwawasan lingkungan sebagai upaya mitigasi banjir perkotaan. Berkelanjutan memberi arti yang dalam terhadap segenap usaha perencanaan yang lebih terukur dan terjamin masa depannya secara terus menerus dan dapat menjadikan solusi yang baik. Adapun berwawasan lingkungan memberi arti adanya upaya pelestarian terhadap lingkungan, yang mana dengan adanya kolam retensi dapat dimanfaatkan untuk peresapan air hujan ke dalam tanah. Namun, dalam perencanaan dan pembangunan kolam retensi teknologi Jepang, perlu dilakukan sharing knowledge atau pembelajaran secara detail serta sosialisasi tentang pemanfaatannya, dan mengkaji sejauh mana sistem kolam retensi ini dapat diadaptasikan di Kota Makassar. Kegiatan pembelajaran dan sosialisasi ini dilakukan bersama pihak Jepang dan 
pemerintah setempat melibatkan lembaga Universitas Hasanuddin sebagai pihak yang dapat menjembatani kegiatan sharing knowledge dari pihak Jepang ke pemerintah setempat dan mengkaji khususnya dalam aspek lingkungan dan keberlanjutan infrastruktur drainase di Kota Makassar.

\section{Latar Belakang Teori}

Di Jepang khususnya di Kota Fukuoka, pada tahun 1999 telah terjadi kerugian yang besar pada saat musim hujan yang mengakibatkan banjir perkotaan dari kurangnya kapasitas fasilitas drainase air hujan (Gambar 1). Hal ini dipicu karena adanya perubahan tutup lahan yang cukup besar mengganggu sistem resapan air hujan dan tidak adanya sistem kolam retensi yang berfungsi untuk mengantisipasi luapan dari sistem drainase kota.

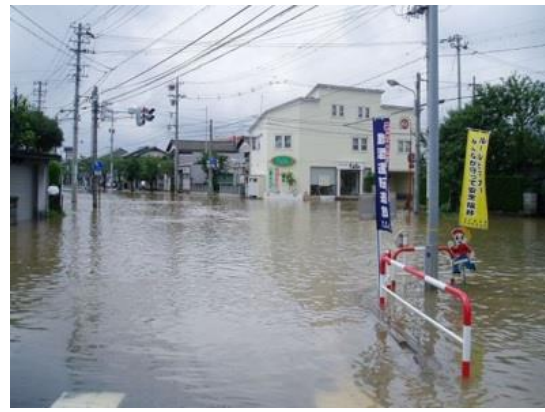

Perumahan

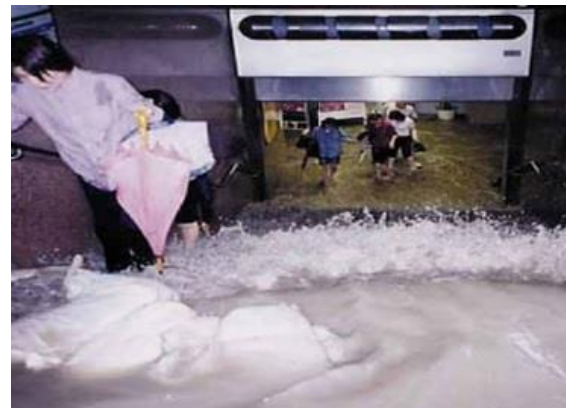

Subway

Gambar 1. Foto keadaan banjir tahun 1999 pada area perumahan dan transportasi subway

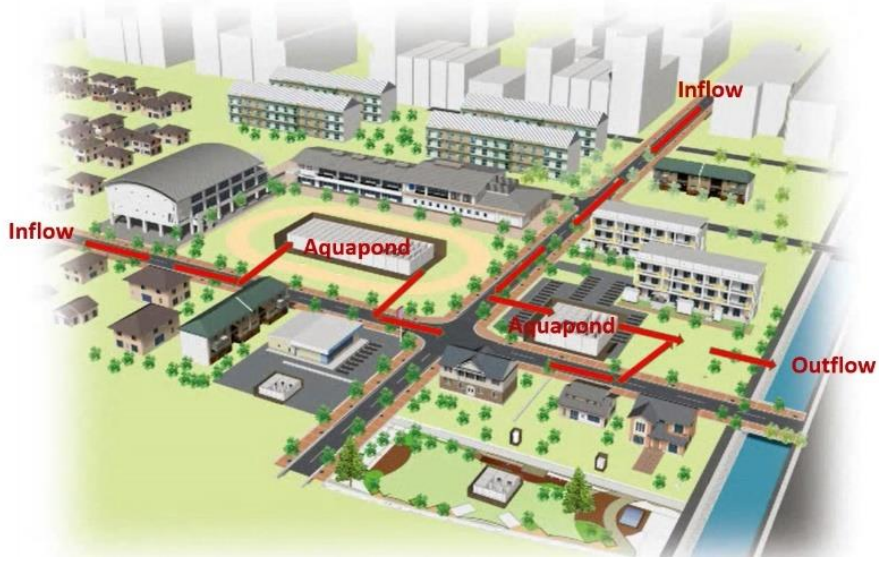

Gambar 2. Sistem pengelolaan drainase air yang memanfaatkan kolam retensi Aquapond

Fasilitas penampungan air hujan menggunakan sistem kolam retensi seperti Aquapond merupakan fasilitas yang menyimpan sementara air hujan di bawah tanah dan mengalirkannya dengan aman pada saat terjadi hujan lebat yang melanda suatu daerah perkotaan (Gambar 2). Air disalurkan dari drainase pada saat saluran akan meluap ke penyimpanan sementara di kolam retensi, dan saat drainase permukaan air turun, air dikeluarkan kembali dari kolam retensi mengalir ke drainase air atau langsung ke sungai melalui penggunaan sistem pompa air ataupun dengan sistem pengaliran gravitasi. Dibandingkan dengan teknologi plastik atau kolam retensi dengan beton cor di tempat cara konvensional, teknologi kolam retensi Aquapond ini adalah 
struktur beton yang terbuat dari unit-unit beton pracetak yang disusun sedemikian rupa menjadi satu struktur yang lebih kuat dan tahan gempa, lebih kompak dan terstandarisasi, dan dimungkinkan untuk merespon kebutuhan sesuai dengan situasi lokal seperti luasan lahan yang ada atau kemiringgan permukaan tanah. Tabel 1 memperlihatkan perbandingan teknologi yang sudah dianalisis untuk kasus-kasus di Jepang. Lingkaran dengan 2 (dua) garis menandakan kemampuan yang tinggi, lingkaran dengan 1 (satu) garis adalah kemampuan sedang, dan tanda segitiga adalah kemampuan yang rendah dalam item-item yang dibandingkan (Yamau Co., Ltd, 2020).

Tabel 1. Perbandingan kolam rentesi menggunakan unit beton pracetak, struktur beton cor di tempat, dan unit plastik (Yamau Co., Ltd, 2020)

\begin{tabular}{|c|c|c|c|c|c|c|}
\hline Item & \multicolumn{2}{|c|}{ Aquapond } & \multicolumn{2}{c|}{ Beton cor di tempat } & \multicolumn{2}{c|}{ Plastik } \\
\hline $\begin{array}{c}\text { Pengaruh air } \\
\text { tanah }\end{array}$ & $\begin{array}{c}\text { Stabil terhadap } \\
\text { daya angkat air }\end{array}$ & $\bigcirc$ & $\begin{array}{c}\text { Stabil terhadap } \\
\text { daya angkat air }\end{array}$ & $\bigcirc$ & $\begin{array}{c}\text { Tidak stabil } \\
\text { terhadap daya } \\
\text { angkat air }\end{array}$ & $\Delta$ \\
\hline Durabilitas & Panjang & $\bigcirc$ & Panjang & $\bigcirc$ & Sedang & $\Delta$ \\
\hline Kualitas & $\begin{array}{c}\text { Stabil karena } \\
\text { buatan pabrik }\end{array}$ & $\bigcirc$ & $\begin{array}{c}\text { Tidak stabil karena } \\
\text { buatan setempat }\end{array}$ & $\Delta$ & $\begin{array}{c}\text { Stabil karena } \\
\text { buatan pabrik }\end{array}$ & $\bigcirc$ \\
\hline Harga & 32 million yen & $\triangle$ & 28.5 million yen & $\bigcirc$ & 26 million yen & $\bigcirc$ \\
\hline konstruksi & Pemasangan bisa \\
15 hari kerja & $\bigcirc$ & $\begin{array}{c}\text { Pemasangan bisa } \\
90 \text { hari kerja }\end{array}$ & $\Delta$ & $\begin{array}{c}\text { Pemasangan bisa } \\
10 \text { hari kerja }\end{array}$ & $\bigcirc$ \\
\hline Maintenance & $\begin{array}{c}\text { Dapat } \\
\text { dimaintence dan } \\
\text { dibersihkan }\end{array}$ & $\bigcirc$ & $\begin{array}{c}\text { Dapat } \\
\text { dimaintenance dan } \\
\text { dibersihkan }\end{array}$ & $\bigcirc$ & $\begin{array}{c}\text { Tidak dapat } \\
\text { dimaintenance } \\
\text { dan dibersihkan }\end{array}$ & $\Delta$ \\
\hline
\end{tabular}
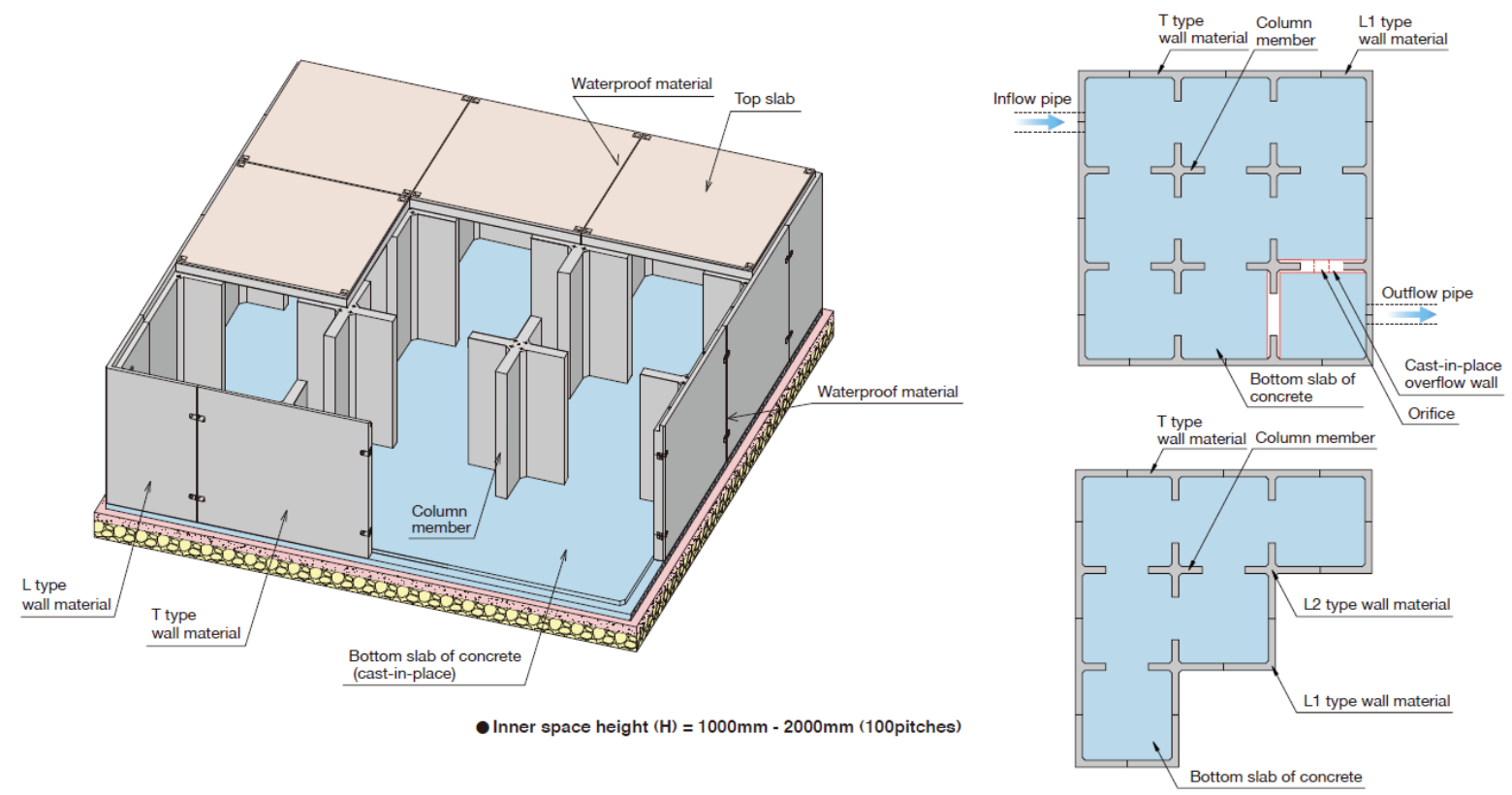

Gambar 3. Contoh tampak 3 (tiga) dimensi dan layout dari Aquapond (Yamau Co., Ltd, 2020) 
Gambar 3 memperlihatkan contoh tampak struktur kolam retensi Aquapond yang terdiri dari unitunit beton, yaitu: unit dinding, kolom dan plat atas, yang dapat disusun sedemikian rupa mengikuti situasi bentuk lahan yang ada. Karena pelat bawah struktur kolam retensi Aquapond adalah beton cor di tempat, maka sangat ekonomis dalam pembuatan konstruksinya. Struktur Aquapond ini menggunakan teknologi beton pracetak, kekuatan dan kualitas yang stabil dapat dipastikan dalam pabrik. Pemasangan sistem beton pracetak dapat mempersingkat waktu konstruksi karena komposisi unit-unit beton pracetak yang efisien.

\section{Metode}

Kota Makasar merupakan salah satu kota terbesar di Indonesia, namun karena keterlambatan pembangunan infrastruktur, banjir pada jalanan dan pemukiman sering terjadi pada musim hujan dikarenakan saluran drainase yang ada saat ini tidak berfungsi maksimal lagi akibat dari penurunan fungsi jaringan air dan adanya perubahan fungsi tutup lahan yang besar (Hanson and Nilsson, 1986). Berdasarkan hal tersebut, dalam menanggapi kebutuhan mendesak akan pembangunan infrastruktur dan untuk perbaikan lingkungan sanitasi dan tindakan mitigasi banjir di Kota Makassar, maka diupayakan pembangunan fasilitas kolam retensi Aquapond yang terhubungkan dengan fasilitas drainase air dalam rangka ujicoba menangani masalah genangan yang sering terjadi pada Jalan Urip Sumohardjo depan kantor gubernur Sulawesi Selatan. Dengan demikian, untuk mempertajam pemahaman tentang Aquapond ini, pemerintah setempat, pihak Jepang, dan department Teknik Lingkungan Universitas Hasanuddin melaksanakan kegiatan seminar dan diskusi sharing knowledge atau pembelajaran tentang perencanaan dan desain, meninjau konstruksi fisik di lapangan, dan melihat secara langsung teknik pemeliharaan serta operasional fasilitas Aquapond, dan kegiatan sosialisasi pengelolaan drainase kota berkelanjutan dan berwawasan lingkungan pada pemerintah Kota Makassar.

\subsection{Perencanaan dan desain}

Dalam perencanaan kolam retensi untuk mitigasi banjir, diperlukan dasar prosedur analisis hidrologi dan kajian hidrolika drainase yang ada (Chow, 1997; Harto, 1993). Prosedur analisis hidrologi dan kajian hidrolik ditunjukkan pada Gambar 4.

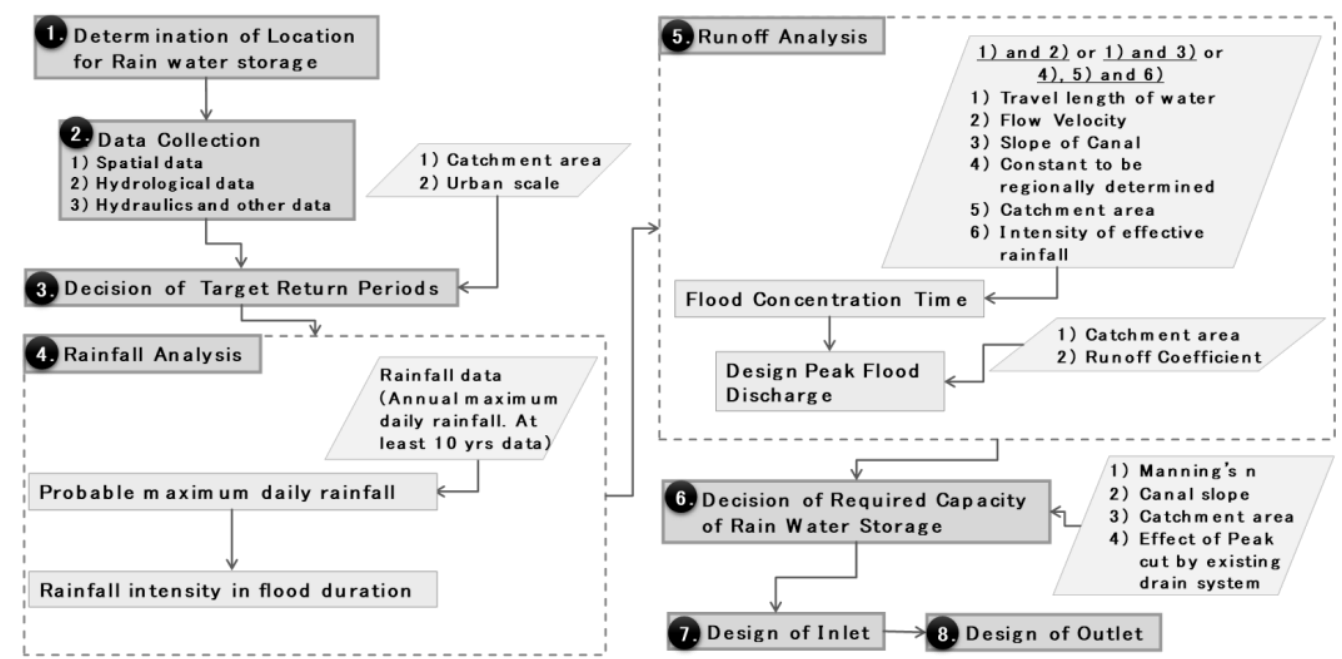

Gambar 4. Flow chart perencanaan kolam retensi untuk mitigasi banjir 
Rincian setiap prosedur yang ditunjukkan pada gambar 4 tersebut diatas dapat dijelaskan di bagian berikut.

\subsubsection{Penentuan lokasi kolam retensi air hujan}

Memilih lokasi kolam retensi air hujan yang tepat diperlukan untuk memaksimalkan efek drainase yang ada (Baurne, 1984). Tata cara penetapan prioritas lokasi dijelaskan menurut peraturan, dan prioritas lokasi ditentukan oleh hal-hal berikut:

- Kriteria parameter genangan

- Kriteria kerugian ekonomi

- Kriteria gangguan sosial dan fasilitas pemerintah

- Kriteria kerugian dan gangguan transportasi

- Kriteria daerah perumahan yang hilang

- Kriteria kerugian milik pribadi

Kriteria ini dievaluasi dan diberi skor dari 0 sampai 100 sesuai dengan peraturan yang menjelaskan metode penilaian. Nilai tertinggi menunjukkan prioritas tertinggi lokasi penyimpanan air hujan.

\subsubsection{Pengumpulan data}

Pengumpulan data yang diperlukan untuk analisis hidrologi dan kajian hidraulik diklasifikasikan menjadi tiga jenis, yaitu: data spasial, data hidrologi, dan data hidrolika seperti di bawah ini.

a) Data spasial

- Data topografi

- Peta penggunaan lahan

- Peta sistem drainase yang ada

- Peta genangan

b) Data hidrologi

- Daerah tangkapan di wilayah sungai

- Data curah hujan

- Data genangan

- Data arus keluar sungai dan saluran air

- Kapasitas penampungan air hujan yang ada

- Pengaruh pemotongan puncak banjir oleh kolam retensi air hujan

c) Data hidrolik

- Spesifikasi saluran, parit dan drainase 
Tabel 2. Kebutuhan perhitungan target periode kembali untuk skala kota

\begin{tabular}{|l|c|c|c|c|}
\hline \multirow{2}{*}{\multicolumn{1}{c|}{ Skala kota }} & \multicolumn{4}{c|}{ Daerah Tangkapan Hujan (ha) } \\
\cline { 2 - 5 } & $\mathbf{1 0}$ & $\mathbf{1 0}-\mathbf{1 0 0}$ & $\mathbf{1 0 0}-\mathbf{5 0 0}$ & $\mathbf{5 0 0}<$ \\
\hline Skala Ibukota & 2 tahun & $2-5$ tahun & $5-10$ tahun & $10-25$ tahun \\
\hline Kota Skala Besar & 2 tahun & $2-5$ tahun & $2-5$ tahun & $5-20$ tahun \\
\hline Kota Skala Sedang & 2 tahun & $2-5$ tahun & $2-5$ tahun & $5-10$ tahun \\
\hline Kota Skala Kecil & 2 tahun & 2 tahun & 2 tahun & $2-5$ tahun \\
\hline
\end{tabular}

\subsubsection{Target periode kembali}

Target periode ulang merupakan faktor keamanan mitigasi bencana banjir. Periode ulang target ditentukan oleh skala perkotaan dan daerah tangkapan dititik masuk kolam retensi air hujan seperti yang ditunjukkan pada Tabel 2 (Ishida, 2003).

\subsubsection{Analisis curah hujan}

a) Kemungkinan Curah Hujan

- Verifikasi data curah hujan

Jika ada dua atau lebih stasiun pengukur curah hujan yang tersedia, sebelum memperkirakan kemungkinan curah hujan, perlu dilakukan validasi setiap data curah hujan. Kurva massa ganda adalah metode utama untuk verifikasi. Ini digunakan untuk memeriksa konsistensi berbagai jenis data hidrologi dengan membandingkan data satu stasiun dengan data pola yang terdiri dari data dari beberapa stasiun lain di daerah target.

- Curah hujan harian maksimum tahunan

Setidaknya sepuluh tahun curah hujan harian maksimum tahunan diperlukan untuk analisis curah hujan.

- Jenis distribusi kurva frekuensi

Berbagai jenis distribusi kurva frekuensi harus dihitung oleh Gumbel, Log Normal (LN) atau Log Pearson Type III, yang direkomendasikan dari Peraturan Menteri No.12 / 2014.

b) Intensitas curah hujan dalam durasi banjir

Jika tidak tersedia data curah hujan per jam untuk wilayah target, intensitas curah hujan dalam durasi banjir dihitung menggunakan rumus formula Mononobe.

\subsubsection{Analisis limpasan}

a) Kondisi perhitungan

- Daerah tangkapan

Daerah tangkapan air di titik masuk kolam retensi air hujan diperlukan. Diperkirakan berdasarkan data topografi.

- Waktu konsentrasi banjir

Waktu konsentrasi banjir diperlukan untuk memperkirakan intensitas curah hujan ratarata selama waktu tersebut. Ini didefinisikan sebagai waktu perjalanan dari titik paling jauh di daerah tangkapan ke titik perkiraan. Ini akan dihitung dengan tiga metode berikut:

1. Metode kecepatan aliran seragam

2. Metode PWRI (Lembaga Penelitian, Jepang) 
3. Metode teori gelombang kinematik

\subsubsection{Penentuan kapasitas kolam retensi dan debit luapan}

Kapasitas aliran saluran drainase dihitung dengan persamaan berikut:

$$
\begin{aligned}
& Q d=A V \\
& V=\frac{1}{n} \cdot R^{\frac{2}{3}} \cdot I^{\frac{1}{2}} \\
& \mathrm{R}=\frac{A}{S} \\
& \text { dimana, } Q_{d}: \text { Kapasitas aliran saluran drainase }\left[\mathrm{m}^{3} / \mathrm{s}\right] \\
& V \quad: \text { Kecepatan aliran }[\mathrm{m} / \mathrm{s}] \\
& A \text { : Area aliran }\left[\mathrm{m}^{2}\right] \\
& n \quad: \text { Koefisien Kekasaran Manning } \\
& R \quad: \text { Radius hidrolik [m] } \\
& I \quad: \text { Kemiringan saluran } \\
& S \quad \text { : Perimeter basah }[\mathrm{m}]
\end{aligned}
$$

Debit luapan dihitung dengan rumus berikut:

$$
Q o=Q p-Q e-Q d
$$

dimana, $Q_{o}:$ Debit luapan $\left[\mathrm{m}^{3} / \mathrm{s}\right]$

$Q_{p}:$ Desain debit puncak $\left[\mathrm{m}^{3} / \mathrm{s}\right]$

$Q_{e}$ : Debit yang dipotong oleh sistem drainase yang ada $\left[\mathrm{m}^{3} / \mathrm{s}\right]$

$Q_{d}:$ Kapasitas aliran di hilir $\left[\mathrm{m}^{3} / \mathrm{s}\right]$

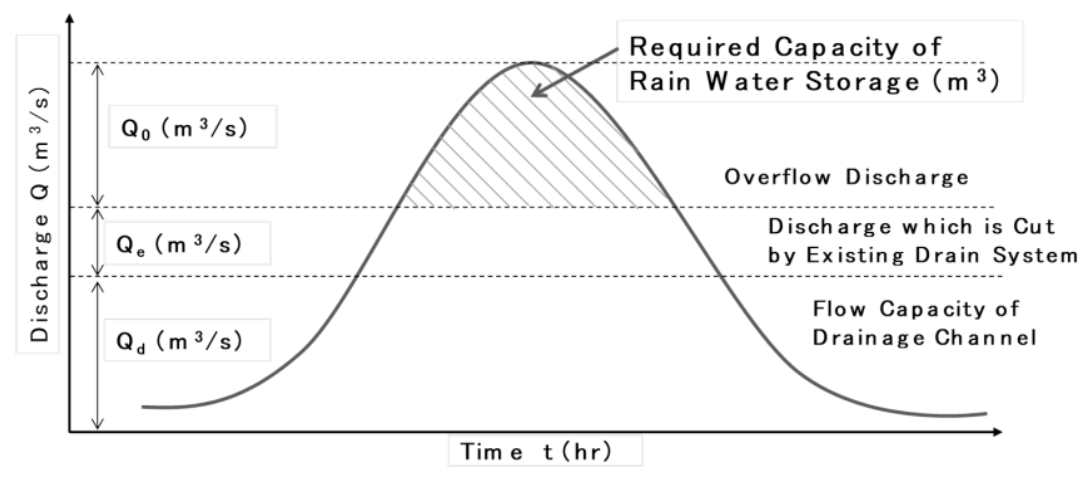

Gambar 5. Garis besar kapasitas yang dibutuhkan kolam retensi air hujan

Kapasitas yang dibutuhkan untuk kolam retensi air hujan ditentukan oleh hidrograf. Gambar 5 mengilustrasikan bagaimana cara mempertimbangkan secara garis besar kapasitas yang dibutuhkan untuk kolam retensi air hujan (Linsley et al., 1983).

\subsubsection{Desain hidrolik inlet dan outlet}

Dua jenis sistem aliran masuk inlet, sebagai berikut.

a) Arus masuk dari channel atau ditch 
Jika ada aliran masuk dari saluran maka perlu dibangun bendung untuk membagi aliran masuk tersebut. Jika kolam retensi air hujan berada di samping saluran (Gambar 6), di bawah atau di depan saluran, maka bendung pelimpah akan dipilih sesuai perhitungan debit masuk.

b) Arus masuk dari side overflow weir

Dengan mempertimbangkan volume aliran masuk dari saluran, maka panjang dan tinggi bendung akan ditentukan (Subarkah, 1980).
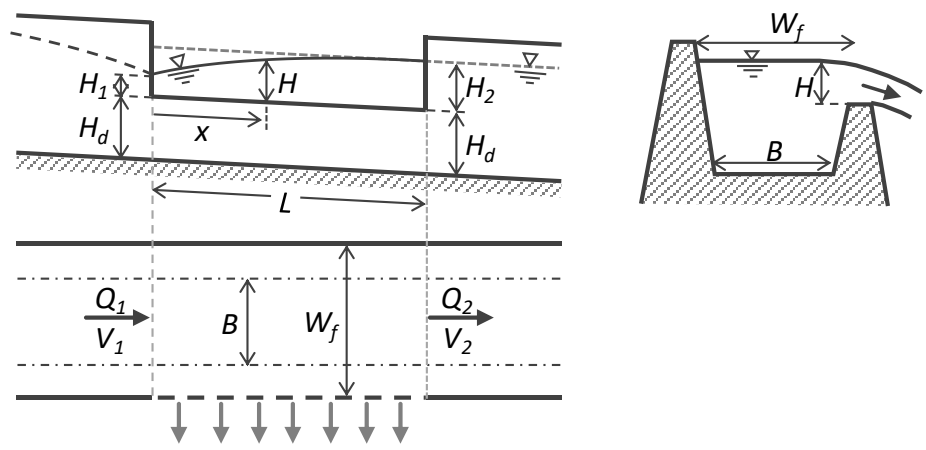

Gambar 6. Contoh perhitungan hidrolik inlet untuk kolam retensi berada di samping saluran

Jika elevasi aliran keluar outlet kolam air hujan lebih tinggi dari elevasi tujuan outflow, debit drainase mengalir ke hilir dengan gaya gravitasi. Kemudian, sistem aliran keluar alami akan dipilih. Penggunaan pompa di mana ketinggian aliran keluar lebih rendah dari elevasi tujuan outflow (Gambar 7).

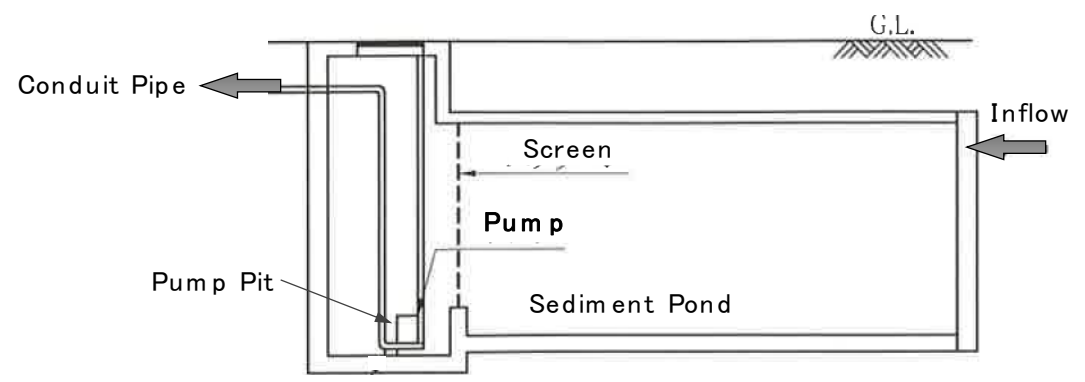

Gambar 7. Garis besar sistem drainase pemompaan dari kolam retensi yang rendah

\subsection{Konstruksi beton pracetak}

Dalam pekerjaan konstruksi kolam retensi ini, beberapa tahapan dilaksanakan sesuai standar pekerjaan konstruksi beton di Jepang (Gambar 8). Tahapan ini terbagi atas:

a) Pekerjaan persiapan antara lain pembersihan lahan dan pembangunan pagar proyek.

b) Pekerjaan dasar pondasi termasuk pekerjaan penggalian dan pengeringan air pada galian.

c) Pekerjaan pondasi beton meliputi pekerjaan pondasi batuan dan pondasi lantai beton.

d) Pekerjaan pemasangan unit beton pracetak terdiri dari installasi unit-unit dan join.

e) Pekerjaan slab bawah termasuk pemasangan tulangan slab dan pengecoran beton.

f) Pekerjaan saluran inlet dan outlet dilakukan sesuai standar desain.

g) Pekerjaan penimbunan ulang adalah tahap penutupan kolam retensi dengan tanah yang dipadatkan sesuai standar konstruksi. 
h) Pekerjaan finishing meliputi pekerjaan pembersihan, lanskap, dan pengembalian fasilitas yang berada diatas kolam retensi.

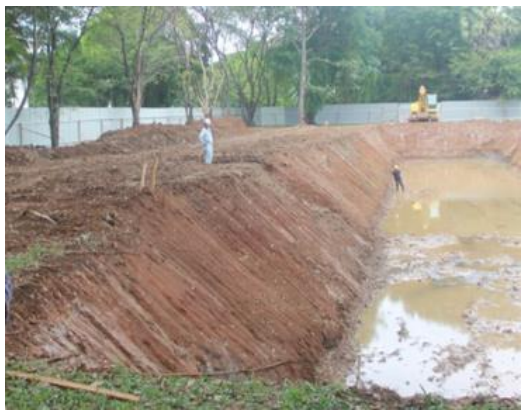

Tahap penggalian

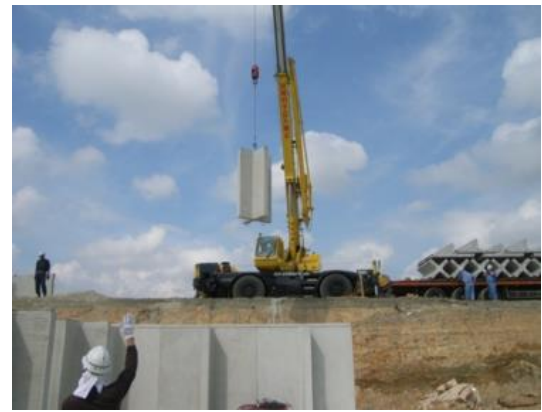

Tahap pemasangan

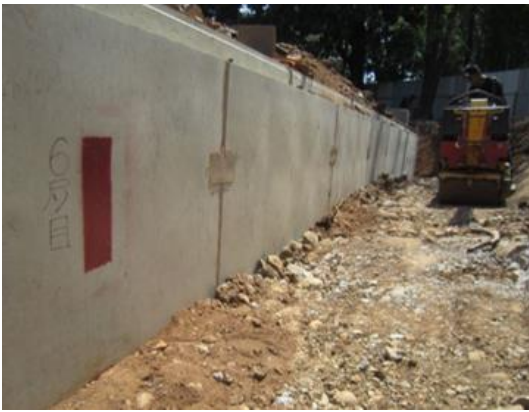

Tahap penimbunan

Gambar 8. Garis besar tahapan konstruksi kolam retensi beton pracetak Aquapond

\subsection{Pemeliharaan fasilitas kolam retensi Aquapond}

\subsubsection{Inspeksi}

Dalam hal pemeriksaan ke dalam kolam retensi Aquapond ini, tindakan keamanan kerja perlu diperhatikan dengan seksama. Terutama, faktor-faktor sebagai berikut:

- Konfirmasi konsentrasi oksigen dan keberadaan gas beracun

- (Adapun standar keamanan, konsentrasi gas oksigen akan lebih dari $18 \%$ dan konsentrasi hidrogen sulfida akan kurang dari $1 \times 10^{-5}$ )

- Ventilasi aktif dengan blower sebelum / selama inspeksi untuk tindakan keamanan.

Ada tiga jenis inspeksi seperti yang ditunjukkan pada Gambar 9 dibawah ini.

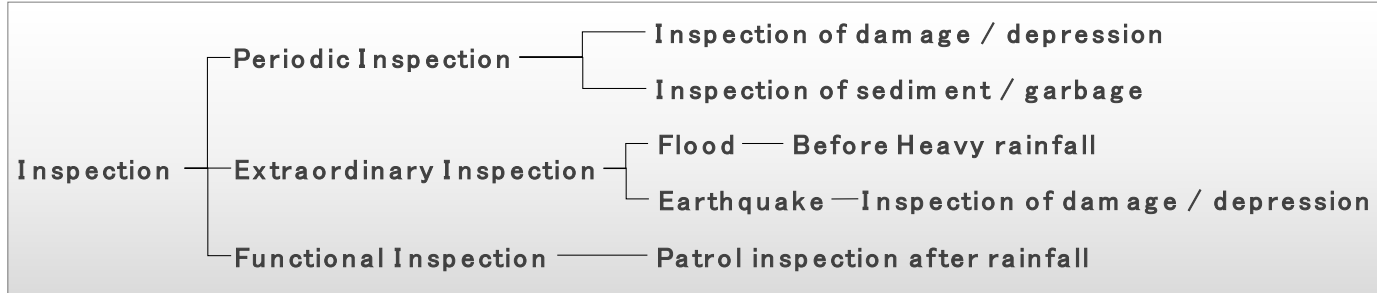

Gambar 9. Jenis dan garis besar inspeksi

\subsubsection{Periode inspeksi}

Pemeriksaan berkala akan dilakukan sebelum musim banjir. Jumlah waktu inspeksi berkala akan ditentukan dengan mempertimbangkan musim hujan, dan keadaan sebenarnya dari setiap wilayah. Contoh periode inspeksi standar dijelaskan pada Tabel 3.

Tabel 3. Contoh standar periode pemeriksaan

\begin{tabular}{|l|l|c|c|c|c|}
\hline \multirow{2}{*}{ Poin inspeksi } & \multirow{2}{*}{ Item } & \multicolumn{4}{|c|}{ Periode inspeksi } \\
\cline { 2 - 5 } & $\begin{array}{c}\text { Setiap } \\
\text { bulan }\end{array}$ & $\begin{array}{c}\text { Setiap 6 } \\
\text { bulan }\end{array}$ & $\begin{array}{c}\text { Setiap 12 } \\
\text { bulan }\end{array}$ & Lainnya \\
\hline
\end{tabular}




\begin{tabular}{|l|l|c|c|c|c|}
\hline \multirow{2}{*}{ Screen } & $\begin{array}{l}\text { Pembersihan sedimen } \\
\text { dan kotoran }\end{array}$ & & & & $\begin{array}{c}\checkmark \text { (Setelah } \\
\text { hujan) }\end{array}$ \\
\hline & Karat dan kerusakan & & $\checkmark$ & & \\
\hline $\begin{array}{l}\text { Sedimen dalam } \\
\text { kolam }\end{array}$ & Pembersihan sedimen & $\checkmark$ & & & \\
\hline Kolam retensi & Dampak sedimen & & & $\checkmark$ & \\
\hline & Pembersihan sedimen & $\checkmark$ & & & \\
\hline Fasilitas lainnya & Dampak pompa & & $\checkmark$ & & \\
\hline
\end{tabular}

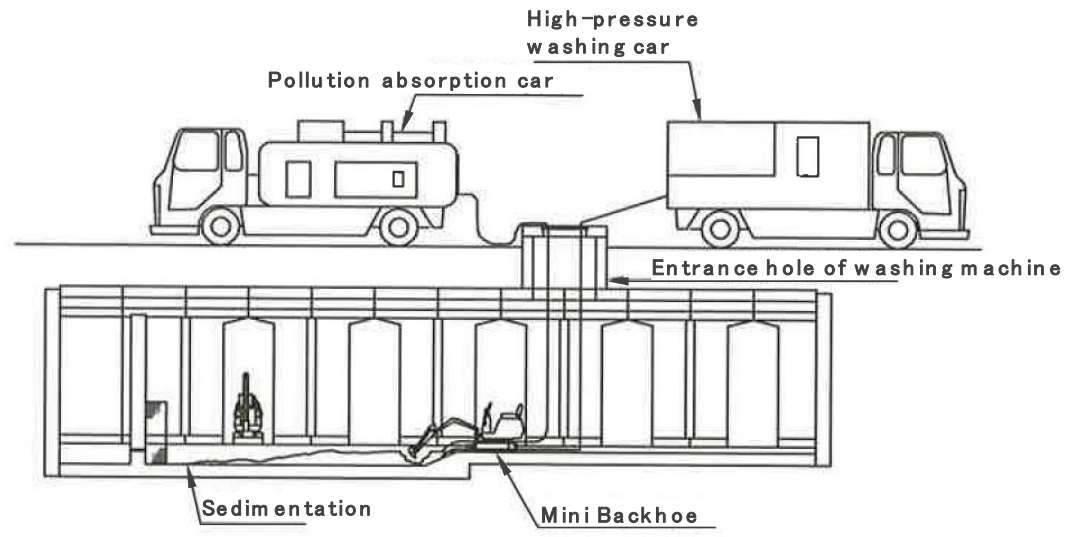

Gambar 10. Membersihkan kolam retensi dengan pencucian mesin pompa dan pengisap

\subsubsection{Metode pembersihan sedimen dengan mesin}

Jika sedimentasi terbatas pada pasir, maka mudah dibersihkan dengan pompa vakum pada hari yang cerah dengan keadaan kering. Jika pencemarannya luar biasa, itu akan dibersihkan dengan air dari pompa bertekanan tinggi (Gambar 10).

Kegiatan ini menargetkan pembelajaran secara menyeluruh dan sekaligus sosialisasi tentang pemanfaatkan kolam retensi bawah tanah di Kota Makassar menggunakan teknologi Jepang untuk mitigasi banjir kepada pemerintah setempat dan masyakarat umum melalui Teknik Lingkungan Universitas Hasanuddin sebagai koordinator dalam kegiatan seminar sharing knowledge. Lebih dari itu, mengkaji bersama-sama dengan pihak Jepang dan pemerintah terkait tentang pengelolaan drainase kota menggunakan fungsi kolam retensi Aquapond dan mendiskusikan problem-solving. Target pencapaian terbagi atas tiga tema pembelajaran, sebagai berikut.

Pembelajaran 1: Perencanaan dan desain

Dalam hal perencanaan dan desain, pembelajaran perbandingan model perhitungan dan perencanaan di Jepang dan di Indonesia yang berdasarkan standar-standar perhitungan umum perencanaan drainase kota dalam upaya penanggulangan banjir perlu dilakukan. Pihak pemerintah dinas Pekerjaan Umum Kota Makassar, khususnya bidang drainase berperan penting dalam penerimaan pembelajaran dan pemahaman secara detail untuk dikaji seberapa besar potensi adaptasi kolam retensi ini dalam pengelolaan drainase Kota Makassar. Hal ini dilakukan bersama departemen Teknik Lingkungan mengkaji aspek lingkungan dan keberlanjutan 
pembangunan infrastruktur Kota Makassar. Pelaksanaan seminar bersama pihak Jepang untuk membahas tahapan seluruh perencanaan dan desain Aquapond.

Pembelajaran 2: Konstruksi beton pracetak Aquapond

Dalam hal kualitas konstruksi, perlunya pihak pemerintah kota terkait dan masyarakat melihat langsung fasilitas yang dibangun dengan mengkaji potensi timbulnya dampak negatif dari adanya kolam retensi bawah tanah tersebut. Bersama dinas Pekerjaan Umum Kota Makassar dan pihak Jepang, diharapkan dapat menjelaskan secara detail tahapan konstruksi yang perlu diperhatikan dalam standar pembangunan Aquapond ini. Sebagai contoh teknik pemasangan unit beton pracetak dengan akurasi tinggi dan kedap air, di mana hal ini masih sangat jarang dilakukan untuk level Kota Makassar.

Pembelajaran 3: Operasional dan pemeliharaan

Pemeliharaan fasilitas yang telah dibangun perlu dipahami dengan baik, sehingga teknis pemeliharaan dan operasional yang efektif dapat dilaksanakan. Dalam hal ini, pemerintah provinsi Sulawesi Selatan adalah pihak yang perlu untuk melakukan kegiatan langsung pemeliharaan dan operasional fasilitas karena terbangun di dalam wilayah kantor gubernur Sulawesi Selatan. Bersama dinas terkait pelaksanaan pembelajaran melalui seminar dan tinjauan langsung di lapangan perlu dilakukan, untuk mengetahui teknis pemeliharaan dan permasalahan seperti contoh dalam pembersihan kotoran sampah dan sedimen yang masuk di dalam kolam retensi.

\section{Hasil dan Diskusi}

Proses pelaksanaan kegiatan pengabdian ini telah melibatkan masyarakat, pemerintah setempat dan pihak Jepang baik dalam proses pembelajaran pada perencanaan dan desain, peninjauan konstruksi, dan tinjauan lapangan operasional dan pemeliharaan fasilitas Aquapond. Implementasi kegiatan ini dapat dijelaskan sebagai berikut.

(1) Kegiatan pembelajaran tentang pengelolaan drainase kota dan perencanaan kolam retensi

Bersama pihak Jepang, pembahasan mengenai pengelolaan drainase kota dan prosedur perencanaan serta desain untuk kolam retensi menggunakan teknologi Jepang. Diskusi tentang adaptasi model, analisis dan perhitungan serta penggunaan data-data oleh Kota Makassar telah dilaksanakan.
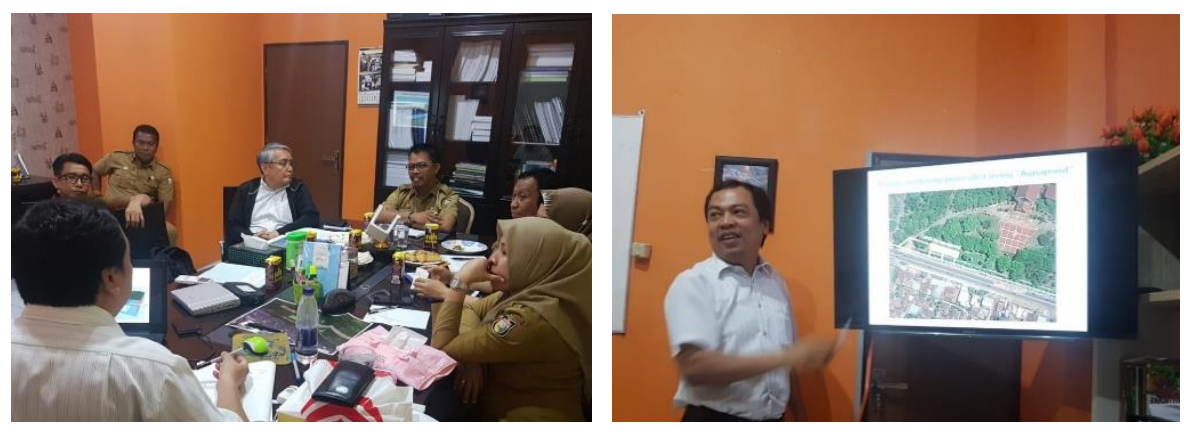

Gambar 11. Diskusi bersama dinas pekerjaan umum Kota Makassar 

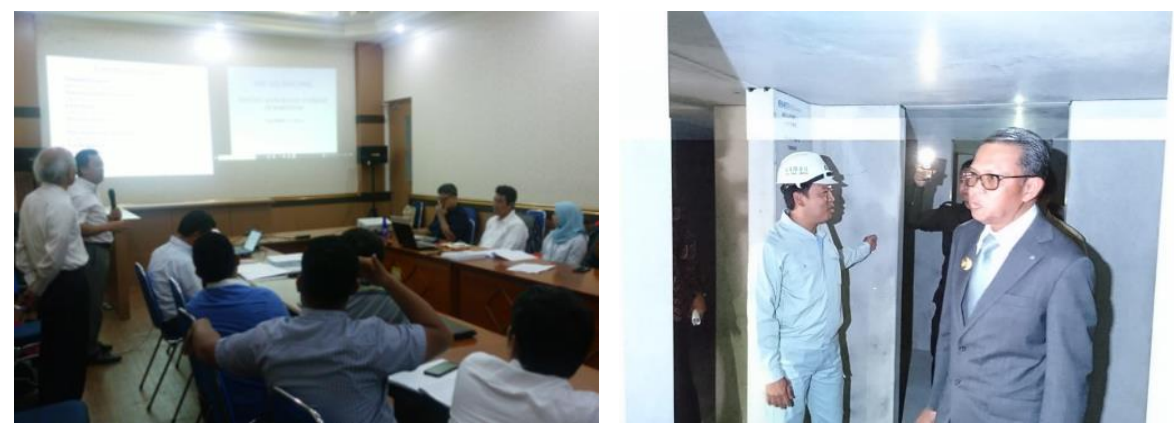

Gambar 12. Diskusi tentang konstruksi dan peninjauan struktur
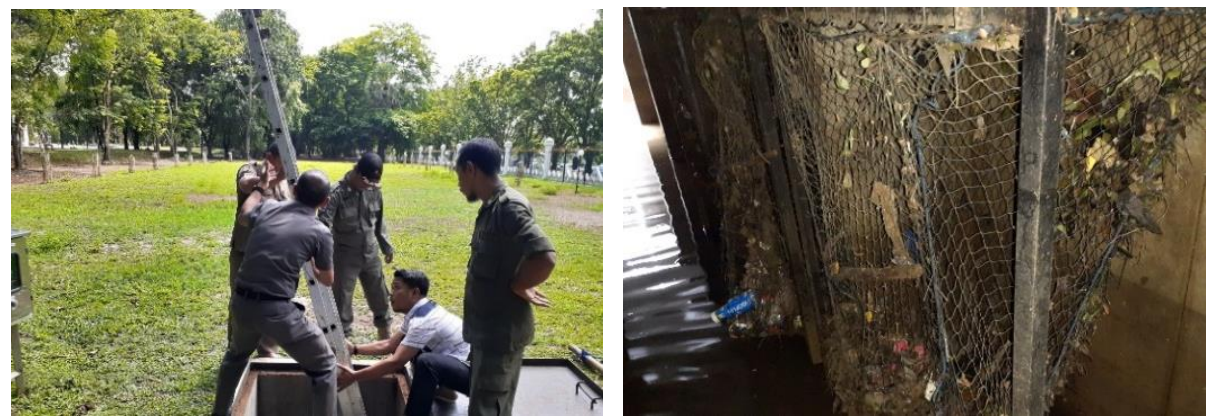

Gambar 13. Peninjauan langsung pemeliharaan akibat sampah

(2) Kegiatan pembelajaran tentang konstruksi dan kualitas struktur

Bersama pihak Jepang, masyarakat dan pemerintah terkait, pembahasan mengenai tahapan konstruksi dan metode instalasi beton pracetak Aquapond telah dibahas. Peninjauan konstruksi yang telah dibangun untuk melihat secara langsung kualitas struktur dan bentuk geometrik dalam kolam retensi telah dilaksanakan.

(3) Kegiatan pembelajaran tentang operasional dan pemeliharaan

Bersama pihak pemerintah setempat, telah dilakukan peninjauan fasilitas serta pembelajaran teknis pemeliharaan dari permasalahan sampah atau sedimen. Pembelajaran tentang cara pembersihan sampah langsung di lapangan berguna untuk mengetahui dengan jelas permasalahan teknis yang ada. Untuk pembelajaran pembersihan dalam kolam retensi, dilakukan peninjauan bersama di dalam kolam melihat kondisi sampah yang masuk melalui saluran inlet. Teknis pembersihan sampah-sampah dalam kolam telah dilaksanakan untuk memastikan pemeliharaan yang efektif.

Proses pelaksanaan kegiatan pengabdian ini telah melibatkan pihak Jepang, pemerintah setempat dan masyakarat. Pelaksanaan diskusi tentang pengelolaan drainase kota, perencanaan dan desain, konstruksi dan pemeliharaan kolam retensi telah dilakukan. Kendala dalam perencanaan kolam retensi seperti Aquapond telah dibahas termasuk dalam tahap pengumpulan data-data. Model analisis hidrologi dan hidrolika saluran air telah didiskusikan dan peraturan-peraturan dalam perencanaan dan pengelolaan drainase kota telah dikaji ulang bersama.

Kegiatan pembelajaran tentang konstruksi standar Jepang termasuk prosedur konstruksi dan teknik pemasangan unit-unit beton pracetak dan peninjauan langsung struktur Aquapond memberikan pemahaman jelas tentang kualitas konstruksi dan perbedaannya. Penjelasan poin- 
poin penting dalam mencapai kualitas yang berstandar Jepang telah didiskusikan. Selain itu, peninjauan struktur kolam retensi telah dilaksanakan dengan tujuan melihat langsung produk kerja dari standar konstruksi Jepang. Hal ini bisa dijadikan dasar studi banding dalam pengembangan infrastruktur drainase Kota Makassar.

Kegiatan peninjauan langsung dilapangan untuk pemeliharaan fasilitas memberikan pembelajaran tentang tata cara pemeliharaan yang tepat dan operasional kolam retensi khususnya terkait pembersihan terhadap sampah-sampah yang masuk kedalam kolam. Sampah yang terjaring dalam kolam dapat diamati dengan jelas, sehingga memberikan pembelajaran yang efektif tentang penanganan permasalahan terkait sampah.

\section{Kesimpulan}

Pembelajaran dalam pengelolaan drainase Kota Makassar yang memasukkan fungsi kolam retensi dalam upaya mitigasi banjir dapat terlaksana dengan baik. Sosialisasi perencanaan fasilitas kolam retensi dapat dilakukan oleh pihak pemerintah setempat untuk upaya penanganan masalah banjir yang sering terjadi. Prosedur perencanaan termasuk dari pengumpulan data, akurasi dan analisis dapat ditingkatkan dengan adanya kegiatan pembelajaran ini. Peninjauan hasil pekerjaan konstruksi beton pracetak Aquapond memberikan pembelajaran yang baik dalam mensosialisasikan peningkatan mutu pekerjaan konstruksi drainase Kota Makassar. Lebih dari itu, pembelajaran pemeliharaan melalui kegiatan peninjauan langsung kolam retensi akibat dari penumpukan sampah dapat diobservasi dengan jelas, sehingga untuk kegiatan sosialisasi perencanaan kolam retensi selanjutnya perlu mengkaji lebih dalam termasuk permasalahan sampah.

\section{Ucapan Terima Kasih}

Ucapan terima kasih kepada Pemerintah Kota Makassar dan Provinsi Sulawesi Selatan dalam keikutsertaannya pada kegiatan pembelajaran melalui sharing knowledge tentang pengelolaan drainase kota, perencanaan dan desain, dan pemeliharaan kolam retensi Aquapond. Penghargaan juga ditujukan kepada pihak Jepang yang telah membantu dalam kegiatan sharing knowledge ini, di mana telah menjelaskan dengan baik tentang kondisi dan mitigasi banjir serta pembangunan infrastruktur kolam retensi Aquapond di Jepang.

\section{Daftar Pustaka}

Anonim. 2019. Rencana Nasional Penanggulangan Bencana 2015-2019.

Ishida, S. et al. (2003) Construction of subsurface dams and their impact on the environment. RMZ - Materials and Geoenvironment, 50, 149-152.

Yamau Co., Ltd, 2020, Product Catalog. http://www.yamau.co.jp/global/products/pickup04

Hanson, G. \& Nilsson, A. (1986) Ground-water dams for rural-water supplies in developing countries. Groundwater, 24(4), 497-506.

Chow, Ven Te. 1997. Hidrolika Saluran Terbuka, Jakarta: Erlangga.Anonim. 1994. Tata Cara Perencanaan Drainase Permukaan Jalan. SK SNI 03-3424-1994 Puslitbang Jalan. Balitbang PU: Jakarta.

Harto, Sri. 1993. Analisis Hidrologi, Jakarta: Erlangga.

Baurne, G. (1984) "Trap-dams": Artificial Subsurface Storage of Water. Water International, 9(1), 2-9. 
Linsley, Ray K., Kohler, Max A. \& Paulus, Joseph L.H. 1983. Hydrology for Engineers Third Edition. Tokyo: Mc Graw Hill.

Subarkah, Imam. 1980. Hidrologi untuk Perencanaan Bangunan Air. 